\title{
Learning Alone - a kapcsolati BEÁGYAZÓDÁS VIZSGÁLATA A TÁVOLLÉTI OKTATÁS ALATT
}

\author{
PUSZTAI GABRIELLA* - GYÖRI KRISZTINA \\ Debreceni Egyetem
}

Beérkezett: 2021. február 7., elfogadva: 2021. február 21.

\begin{abstract}
A COVID-19-pandémia oktatásra gyakorolt hatását 2020-ban a kutatók rendkívüli gyorsasággal kezdték el vizsgálni. Jelen kutatás összehasonlította a hallgatói kapcsolatoknak a vészhelyzeti távolléti oktatás (emergency remote teaching, ERT) előtti és alatti állapotát és ezek összefüggését a hallgatói eredményesség alakulásával. Kérdőívünket 677 válaszadó hallgató töltötte ki (172 férfi és 505 nő) összesen 29 magyarországi felsőoktatási intézményből. Eredményeink rámutattak az oktatók tanítással nem szorosan összefüggő szerepköreinek nélkülözhetetlenségére, valamint arra, hogy a hallgatói kapcsolatok gyengülése összefüggésben áll a tanulmányok melletti kitartással, a tanulmányi aktivitással, a bizalommal és az elégedettséggel. Mindezt a virtuális egyetem koncepciók kidolgozásánál is szükséges figyelembe venni.
\end{abstract}

Kulcsszavak: COVID-19, oktatás, távoktatás, sürgősségi távolléti oktatás, lemorzsolódás, felsőoktatás, virtuális egyetem

Researchers have begun studying with utmost haste the effect of the COVID-19 pandemic on teaching already in 2020. In the present study, we compared the states of the student relationships before and after the emergency remote teaching (henceforth ERT). Our questionnaire was filled by 677 students (172 males, 505 females) from altogether 29 Hungarian higher education institutes. Our results raise attention to the important dimension of the role of faculty members which are not in close relation to knowledge transfer, furthermore, the results point that the strength of the institutional relationships is in correlation with the persistence related to student persistence, student engagement, the trust, and the satisfaction. All of this should be taken into consideration when working out a concept for a virtual university.

Keywords: COVID-19, education, emergency remote teaching, drop out, higher education, virtual university

* Levelező szerző: Pusztai Gabriella, Debreceni Egyetem, 4032 Debrecen, Egyetem tér 1.
Email: pusztai.gabriella@arts.unideb.hu 


\section{Bevezetés}

$\mathrm{A}$ COVID-járvány az élet más területei mellett felforgató hatással volt az oktatás legtöbb szegmensére. Mivel a helyzet megakadályozta a hagyományos oktatás zökkenőmentes folytatását, a közvetlen kontaktusok nélküli munkarendben működött a rendszer. Az átállás során a felsőoktatás több rejtett hiányossága került napvilágra. A közhiedelemmel ellentétben a járvány okozta oktatási munkarend nem a távoktatásnak felel meg, ugyanis lényeges különbségek vannak a 2020-ban világszerte kialakult különféle gyakorlatok és a valódi távoktatás között. A járványhelyzet alatti távoktatást a szakirodalom sürgősségi távolléti oktatásnak (emergency remote teaching, ERT) nevezi, ami több lényeges ponton (mint például átgondoltság, ellenőrző értékelő módszerek, szervezettség) eltér a valódi távoktatási munkarendtől (Hodges et al. 2020). A kutatók rendkívüli érdeklődéssel kezdték el vizsgálni a kialakult helyzetet, aminek köszönhetően számos friss elemzés született. Górcső alá vették a távolléti oktatás platformjait (Ferdig et al. 2020; Kristóf 2020; Engler 2020), a hallgatók és oktatók IKT-jártasságát, infrastrukturális ellátottságát és attitűdjeiket (Ferdig et al. 2020; Rapanta et al. 2020), valamint az oktatáspolitikai szempontokat is (Hodges et al. 2020; Williamson-Eynon-Potter 2020). Azt azonban nem vizsgálták, hogy a járványhelyzet következményeként a hallgatók kapcsolatrendszerének nagymértékü redukciója milyen összefüggésben áll a hallgatói eredményességgel.

\section{Miért gond, ha a hallgató magányos?}

A világjárvány okozta kétségbeesés alapjaiban ingathatja meg a hallgatók jövőterveit, s ezáltal a tanulmányok melletti kitartását is. Természetesen ez nem vezet egyből lemorzsolódáshoz, de nem kerülheti el a kutatók figyelmét. Tinto (1975) munkája során megállapította, hogy a hallgatók intézményen belüli kapcsolatok és interakciók híján nagyobb eséllyel hagyják félbe tanulmányaikat. A hallgató intézményi interakcióinak szegényessége gyengíti a tanulmányi erőfeszítéseiket, gyengítheti a diplomaszerzésük sikerébe vetett hitüket, illetve csökkenti tanulmányi eredményességüket (Tinto 1975; Astin 1993). Az intézményen belüli extrakurrikuláris tevékenységeket és a hallgatóoktató kapcsolatokat a hazai kutatások is benntartó erőként azonosították (Pusztai 2011). Megfontolandó, hogy mind a távoktatás, mind a távolléti oktatás járványmentes időszakban financiális és praktikus előnyeik mellett erősíthetik a lemorzsolódási kockázatot a hallgatók számára, mivel az iskolai rítusok, a hallgatói és az oktatói kapcsolatok, s ezzel együtt az intézményhez és a felsőfokú tanulmányokhoz füződő kötelékek redukálódnak. Azt gondolhatnánk, hogy a 21. századi, potenciálisan akár globálissá bővülő, virtuális társadalmi tőke (virtual social capital), amely magában foglalja a hallgatók közötti közösségi hálózatokat, képes a világjárvány okozta társadalmi kapcsolattartás hiányát pótolni (Arkhipova et al. 2020), azonban a 2020. évi nemzetközi kutatások kimutatták, hogy a kényszerủ távolléti oktatásban a személytelenséget nagyon hamar motiválatlanság követi (Niemi-Kousa 2020).

Ennek tükrében kutatásunk legfőbb célja nem a távoktatási módszerek és technológiai megoldások vizsgálata, hanem a távoktatásból sokszor nélkülözött intra- és intergenerációs kapcsolatok távolléti oktatás alatt érzékelt hiányának vizsgálata a le- 
morzsolódási kockázat szempontjából. Joggal merülhet fel a kérdés, hogy a járványhelyzet alatt a hallgatói kapcsolatok csökkenésével összefüggésben romlanak-e a hallgatói eredményesség mutatói. Feltételezésünk szerint az intézményi beágyazottság csökkenése a hallgatói továbbhaladás és eredményesség elbizonytalanodását vonja maga után.

\section{A kutatásról: mintajellemzők, alkalmazott mutatók}

A kutatási kérdésünk megválaszolásának érdekében kérdőíves vizsgálatot végeztünk a távolléti oktatás első szakaszában (2020. május-június). A „Learning Alone” című kérdőív két szerkezeti egységből állt. Az első egységben a távolléti oktatás előtti tapasztalatokat mértük retrospektíven, majd a második egységben, ugyanazon kérdésekkel vizsgáltuk a válaszadók távolléti oktatás alatti helyzetértékelését. Hat hét alatt 677 hallgató töltötte ki a kérdőívet (172 férfi és 505 nő) összesen 29 magyarországi felsőoktatási intézményből. ${ }^{2}$ A válaszadók 14 képzésterületről kerültek ki, 46\%-uk a képzésük elején, 38\%-uk a képzésük közepén, 16\%-uk a képzésük végén járt. A válaszadók átlag életkora 21,7 (18-30) év. A hallgatók szülei közül legtöbben felsőfokú végzettséggel $(46,7 \%)$ rendelkeztek, őket a középfokú végzettséggel $(40,8 \%)$ rendelkezők követték, míg az alapfokú iskolázottságú szülők voltak a legkevesebben a válaszadók között $(12,4 \%)$. A kutatási kérdésekre a CHERD-Hungary által kifejlesztett IESA (Effects of Institutional Integration On Student Achievement In Higher Education) és PERSIST kérdőív bizonyos blokkjainak felhasználásával vagy továbbfejlesztésével kerestük a választ a saját fejlesztésü kérdések mellett. Az IESA kérdőívből a hallgatói kapcsolati háló (Cronbach-alfa 0,798) és az IKT-használati (Cronbach-alfa 0,588) blokkot adaptáltuk, míg a PERSIST kérdőívből az eredményesség mutatóira vonatkozó, azaz a bizalomra (Cronbach-alfa 0,851), az elégedettségre (Cronbach-alfa 0,923) és a perzisztenciára, illetve az elkötelezettségre (Cronbach-alfa 0,841 ) vonatkozó kérdéseket vettük át.

\section{Eredmények}

Első lépésben a hallgatók felsőoktatási perzisztenciájának, elkötelezettségének, bizalmának és elégedettségének változását vizsgáltuk, melyek szignifikánsan csökkentek. A legjelentősebb csökkenést a tanulmányi aktivitás területén tapasztaltuk (a hallgatók 62,8\%-ánál). Ezt követte a bizalom csökkenését jelzők aránya (50,2\%) és az intézménynyel elégedetlenek aránya (50,2\%). A tanulmányok folytatása melletti kitartás csökkenése ennél valamivel kevesebbeket érintett (40\%). Az előbbi mutatók csökkenését érzékelők egyik szülői iskolázottsági csoportban sem voltak felülreprezentálva. Ezután a második

1 Utalás Robert Putnam Bowling Alone: The Collapse and Revival of American Community című könyvére (Putnam 2000).

2 Állatorvosi Egyetem, Budapesti Corvinus Egyetem, Budapesti Gazdasági Egyetem, Budapesti Metropolitán Egyetem, Budapesti Műszaki- és Gazdaságtudományi Egyetem, Debreceni Egyetem, Debreceni Református Hittudományi Egyetem, Dunaújvárosi Egyetem, Edutus Egyetem, Eötvös Loránd Tudományegyetem, Eszterházy Károly Egyetem, Gábor Dénes Főiskola, Gál Ferenc Főiskola, Kaposvári Egyetem, Károli Gáspár Református Egyetem, Kodolányi János Egyetem, Miskolci Egyetem, Nemzeti Közszolgálati Egyetem, Neumann János Egyetem, Nyíregyházi Egyetem, Óbudai Egyetem, Pannon Egyetem, Pázmány Péter Katolikus Egyetem, Pécsi Tudományegyetem, Semmelweis Egyetem, Soproni Egyetem, Széchenyi István Egyetem, Szegedi Tudományegyetem, Szent István Egyetem 
lépésben a hallgatói kapcsolatok szerkezetének és intenzitásának összevetését végeztük el. Azt tapasztaltuk, hogy a kapcsolattartás a szülő-hallgató kapcsolatokon kívül mindenhol szignifikánsan szegényesebb lett. A legjobban az intragenerációs kapcsolatok lazultak, fóként a hallgatótársakkal gyengült a kontaktus (59\%) (1.ábra).

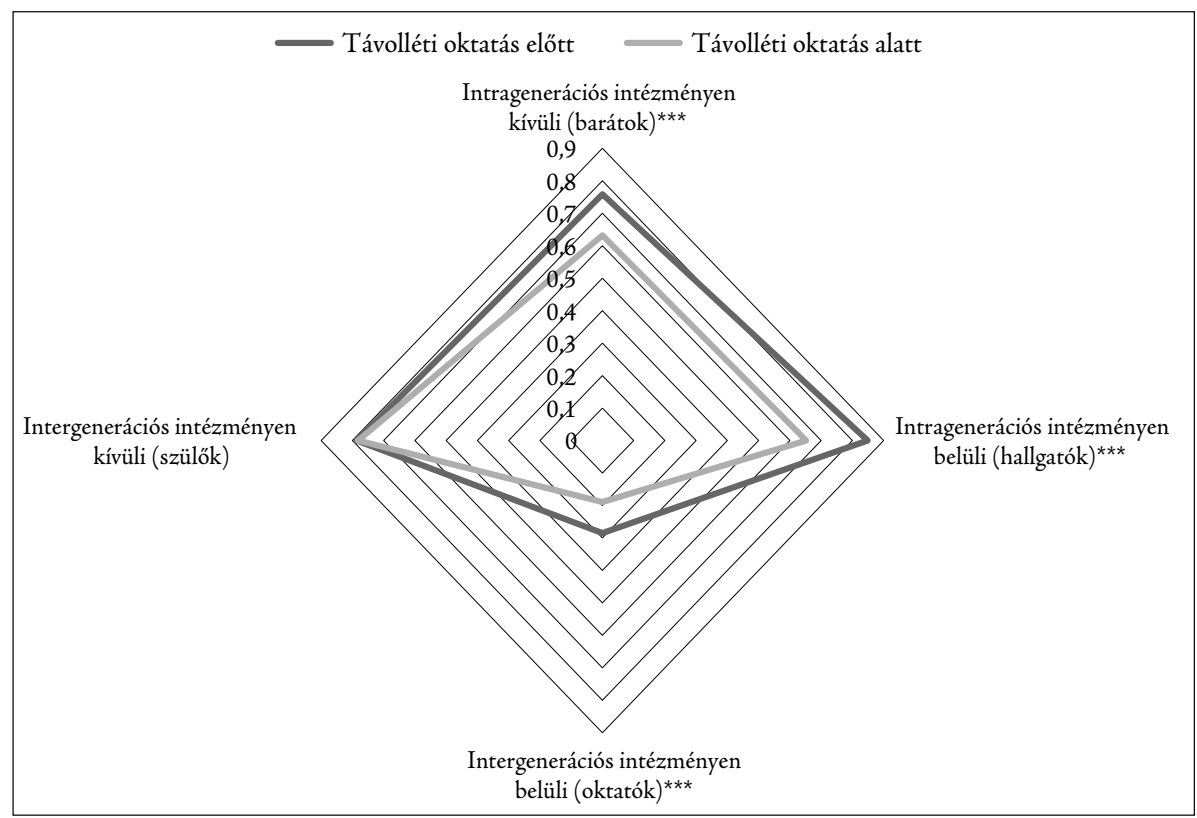

1. ábra: A hallgatói kapcsolati hálók 0 és 1 közötti értékeinek átlaga Megjegyzés: Páros mintás t-próba, ${ }^{*} \leq 0,05 ;^{* *} \leq 0,01 ;{ }^{* * *} \leq 0,001$

Forrás: Learning Alone $(N=677)$

A kapcsolattartás csökkenése társadalmi háttérre való tekintet nélkül egyformán sújtott minden hallgatót. Mivel a tanulmányi kitartás, a tanulmányi aktivitás, a bizalom és az elégedettség átlagértékei a két időszak között számottevő különbséget mutattak, indokolttá vált összefüggésvizsgálatok elvégzése. Elsőként a tanulmányok melletti kitartás átlagértékeit vizsgáltuk. Khi-négyzet próba alapján szignifikáns eredmények az intragenerációs intézményen belüli $(p<0,01)$, az intragenerációs intézményen kívüli $(p<0,01)$, valamint az intergenerációs intézményen kívüli $(p<0,01)$ kapcsolatokkal születtek.

Kiemelt figyelemmel vizsgálódtunk az intragenerációs intézményen belüli kapcsolatok változása esetében, hiszen a korábbi kutatások szerint ezek a kapcsolatok erős öszszefüggést mutatnak a tanulmányok melletti kitartással (Tinto 1975; Astin 1993; Pusztai 2011). Jelen adataink is megerősítették ezt. Mindebből arra lehet következtetni, hogy a távolléti oktatás időszakában nélkülözött hallgatói kapcsolattartást az online kontaktusok sem tudták megfelelően pótolni (1. táblázat). 
1. táblázat: Az intragenerációs intézményen belüli kapcsolatok és a tanulmányi kitartás összefüggése (\%)

\begin{tabular}{lccc}
\hline & \multicolumn{3}{c}{ Tanulmányi kitartás változása } \\
\cline { 2 - 4 } $\begin{array}{l}\text { Intragenerációs intézményen } \\
\text { belüli kapcsolatok változása }\end{array}$ & $\begin{array}{c}\text { Csökkent a } \\
\text { tanulmányi kitartás } \\
(N=274)\end{array}$ & $\begin{array}{c}\text { Nem változott a } \\
\text { tanulmányi kitartás } \\
(N=230)\end{array}$ & $\begin{array}{c}\text { Növekedett a } \\
\text { tanulmányi kitartás } \\
(N=173)\end{array}$ \\
\hline $\begin{array}{l}\text { Csökkentek az } \\
\text { intragenerációs intézményen } \\
\text { belüli kapcsolatok }\end{array}$ & $\mathbf{6 4 , 2}$ & 47,4 & 64,2 \\
\hline $\begin{array}{l}\text { Nem változtak az } \\
\text { intragenerációs intézményen } \\
\text { belüli kapcsolatok }\end{array}$ & 31,4 & $\mathbf{4 3 , 0}$ & 30,1 \\
\hline $\begin{array}{l}\text { Növekedtek az } \\
\text { intragenerációs intézményen } \\
\text { belüli kapcsolatok }\end{array}$ & 4,4 & $\mathbf{9 , 6}$ & 5,8 \\
\hline $\begin{array}{l}\text { Összesen } \\
\text { Onyyy}\end{array}$ & 100,0 & 100,0 & 100,0 \\
\hline
\end{tabular}

Megjegyzés: Khi-négyzet próba, $p<0,001$, félkövérrel jelölve: adj. res. $>2$.

Forrás: Learning Alone adatbázis

A várakozással szemben az intergenerációs intézményen belüli kapcsolatok változása nem mutatott szignifikáns összefüggést a tanulmányi kitartás változásával $(p>0,1)$. Vélhetően ennek az az oka, hogy a magyar felsőoktatás oktatói alacsony arányban vesznek részt a hallgatók mentorálásában és tutorálásában (Pusztai 2011).

Az eddigi kutatások az intragenerációs intézményen kívüli kapcsolatok változásának tanulmányi kitartására gyakorolt hatásáról vegyes eredménnyel számolnak be, ugyanis ezek a hallgatói kapcsolatok bizonyos esetekben ösztönzik a hallgatókat a diplomaszerzésre, míg máskor épp ellenkezőleg (Pusztai 2011). Jelen adatok esetében azonban elmondható, hogy az intézményen kívüli barátokkal meglazult kapcsolatok inkább valószínűsítik a válaszadók tanulmányok melletti kitartásának csökkenését (2. táblázat).

2. táblázat: Az intragenerációs intézményen kívüli kapcsolatok és a tanulmányi kitartás összefüggése (\%)

\begin{tabular}{lccc}
\hline & \multicolumn{3}{c}{ Tanulmányi kitartás változása } \\
\cline { 2 - 4 } $\begin{array}{l}\text { Intragenerációs intézményen } \\
\text { kívüli kapcsolatok változása }\end{array}$ & $\begin{array}{c}\text { Csökkent a } \\
\text { tanulmányi kitartás } \\
(N=274)\end{array}$ & $\begin{array}{c}\text { Nem változott a } \\
\text { tanulmányi kitartás } \\
(N=230)\end{array}$ & $\begin{array}{c}\text { Növekedett a } \\
\text { tanulmányi kitartás } \\
(N=173)\end{array}$ \\
\hline $\begin{array}{l}\text { Csökkentek az } \\
\text { intragenerációs intézményen } \\
\text { kívüli kapcsolatok }\end{array}$ & $\mathbf{5 3 , 3}$ & 37,4 & 47,4 \\
\hline $\begin{array}{l}\text { Nem változtak az } \\
\text { intragenerációs intézményen } \\
\text { kívüli kapcsolatok }\end{array}$ & 36,1 & $\mathbf{4 3 , 0}$ & 38,7 \\
\hline
\end{tabular}


2. táblázat: (folyt.)

\begin{tabular}{lccc}
\hline & \multicolumn{3}{c}{ Tanulmányi kitartás változása } \\
\cline { 2 - 4 } $\begin{array}{l}\text { Intragenerációs intézményen } \\
\text { kívüli kapcsolatok változása }\end{array}$ & $\begin{array}{c}\text { Csökkent a } \\
\text { tanulmányi kitartás } \\
(N=274)\end{array}$ & $\begin{array}{c}\text { Nem változott a } \\
\text { tanulmányi kitartás } \\
(N=230)\end{array}$ & $\begin{array}{c}\text { Növekedett a } \\
\text { tanulmányi kitartás } \\
(N=173)\end{array}$ \\
\hline $\begin{array}{l}\text { Növekedtek az } \\
\text { intragenerációs intézményen } \\
\text { kívüli kapcsolatok }\end{array}$ & 10,6 & 13,0 & 13,9 \\
\hline Összesen & 100,0 & 100,0 & 100,0 \\
\hline
\end{tabular}

Megjegyzés: Khi-négyzet próba, $p<0,01$, félkövérrel jelölve: adj. res. $>2$.

Forrás: Learning Alone adatbázis

A szülőkkel való kapcsolattartás tekintetében a legtöbb személynél nem történt változás (48,3\%). Náluk a tanulmányok melletti kitartásban sem ment végbe változás. A hallgatók többnyire hazaköltöztek a távolléti oktatás időszakára, de azoknál, akik nem így tettek, az intergenerációs intézményen kívüli kapcsolataik gyengültek, s ez együtt járt a tanulmányi kitartás romlásával (36,1\%) (3. táblázat).

3. táblázat: Az intergenerációs intézményen kívüli kapcsolatok és a tanulmányi kitartás összefüggése (\%)

\begin{tabular}{lccc}
\hline & \multicolumn{3}{c}{ Tanulmányi kitartás változása } \\
\cline { 2 - 4 } $\begin{array}{l}\text { Intragenerációs intézményen } \\
\text { kívüli kapcsolatok változása }\end{array}$ & $\begin{array}{c}\text { Csökkent a } \\
\text { tanulmányi kitartás } \\
(N=274)\end{array}$ & $\begin{array}{c}\text { Nem változott a } \\
\text { tanulmányi kitartás } \\
(N=230)\end{array}$ & $\begin{array}{c}\text { Növekedett a } \\
\text { tanulmányi kitartás } \\
(N=173)\end{array}$ \\
\hline $\begin{array}{l}\text { Csökkentek az } \\
\text { intergenerációs intézményen } \\
\text { kívüli kapcsolatok }\end{array}$ & 34,7 & $\mathbf{4 8 , 3}$ & 44,5 \\
\hline $\begin{array}{l}\text { Nem változtak az } \\
\text { intergenerációs intézményen } \\
\text { kívüli kapcsolatok }\end{array}$ & 36,1 & 22,2 & 25,4 \\
\hline $\begin{array}{l}\text { Növekedtek az } \\
\text { intergenerációs intézményen } \\
\text { kívüli kapcsolatok }\end{array}$ & 29,2 & 29,6 & 30,1 \\
\hline $\begin{array}{l}\text { Összesen } \\
\text { Ón }\end{array}$ & 100,0 & 100,0 & 100,0 \\
\hline
\end{tabular}

Megjegyzés: Khi-négyzet próba, $p<0,01$, félkövérrel jelölve: adj. res. $>2$.

Forrás: Learning Alone adatbázis

Mivel tudjuk, a lemorzsolódás egyik meghatározó tényezője a tanulmányi aktivitás erőssége, a hallgatói kapcsolati dimenziók mindegyikére megvizsgáltuk a változással való összefüggéseket. A minta több mint felét képezték azok a hallgatók, akiknél csökkent a tanulmányi aktivitás. A tanulmányi aktivitás az intragenerációs intézményen belüli $(p<0,01)$ és az intergenerációs intézményen kívüli kapcsolatok változásával $(p<0,001)$ mutatott szignifikáns összefüggést. 
A csökkenő tanulmányi aktivitást mutatók majd kétharmadát képezték azok a hallgatók, akiknél gyengült az intragenerációs intézményen belüli kapcsolattartás. Ez az eredmény - a tanulmányi kitartásnál tapasztaltakhoz hasonlóan - a hallgatótársakhoz kötődő kapcsolatok fontosságát erősíti meg, s rávilágít az együtt tanulás, a közös munkaszervezés szerepére (4. táblázat).

4. táblázat: $\mathrm{Az}$ intragenerációs intézményen belüli kapcsolatok és a tanulmányi aktivitás összefüggése (\%)

\begin{tabular}{lccc}
\hline & \multicolumn{3}{c}{ Tanulmányi aktivitás változása } \\
\cline { 2 - 4 } $\begin{array}{l}\text { Intragenerációs intézményen } \\
\text { belüli kapcsolatok változása }\end{array}$ & $\begin{array}{c}\text { Csökkent a } \\
\text { tanulmányi } \\
\text { aktivitás }(N=425)\end{array}$ & $\begin{array}{c}\text { Nem változott } \\
\text { a tanulmányi } \\
\text { aktivitás }(N=87)\end{array}$ & $\begin{array}{c}\text { Növekedett } \\
\text { a tanulmányi } \\
\text { aktivitás }(N=165)\end{array}$ \\
\hline $\begin{array}{l}\text { Csökkentek az } \\
\text { intragenerációs intézményen } \\
\text { belüli kapcsolatok }\end{array}$ & $\mathbf{6 4 , 0}$ & 44,8 & 51,5 \\
\hline $\begin{array}{l}\text { Nem változtak az } \\
\text { intragenerációs intézményen } \\
\text { belüli kapcsolatok }\end{array}$ & 31,1 & 46,0 & 39,4 \\
\hline $\begin{array}{l}\text { Növekedtek az } \\
\text { intragenerációs intézményen } \\
\text { belüli kapcsolatok }\end{array}$ & 4,9 & 9,2 & 9,1 \\
\hline \begin{tabular}{l} 
Összesen \\
\hline
\end{tabular} & 100,0 & 100,0 & 100,0 \\
\hline
\end{tabular}

Megjegyzés: Khi-négyzet próba, $p<0,01$, félkövérrel jelölve: adj. res. $>2$.

Forrás: Learning Alone adatbázis

Döntően növekedett a tanulmányi aktivitásuk azoknak, akik nem változtattak szüleikkel való kapcsolattartásukon. A tanulmányi aktivitásukból veszítő hallgatók egyharmadát képezték azok, akik a szüleiktől kevesebb támogatást kaptak (32,5\%), igaz, egy másik csoportban a tanulmányi aktivitás csökkenése a szülői kapcsolatok erősödésével járt (31,1\%). Úgy véljük, ezek voltak azok a hallgatók, akikre egyszerre nehezedett a tanulás és az otthoni, családi teendők kötelezettsége. Valószínűleg a családokhoz hazaköltözve hely- és eszközhiány is nehezítette a helyzetüket. Ez az eredmény a távoktatási formák egy sajátosságára, a családi közegben való tanulás komplikáltságára, a jó minőségü kollégiumi férőhelyek fontosságára hívja fel a figyelmet (5. táblázat).

5. táblázat: Az intergenerációs intézményen kívüli kapcsolatok és a tanulmányi aktivitás összefüggése (\%)

\begin{tabular}{lccc}
\hline \multirow{2}{*}{$\begin{array}{l}\text { Intragenerációs intézményen } \\
\text { kívüli kapcsolatok változása }\end{array}$} & $\begin{array}{c}\text { Csökkent a } \\
\text { tanulmányi } \\
\text { aktivitás }(N=425)\end{array}$ & $\begin{array}{c}\text { Nem változott } \\
\text { a tanulmányi } \\
\text { aktivitás }(N=87)\end{array}$ & $\begin{array}{c}\text { Növekedett } \\
\text { a tanulmányi } \\
\text { aktivitás }(N=165)\end{array}$ \\
\hline $\begin{array}{l}\text { Csökkentek az } \\
\text { intragenerációs intézményen } \\
\text { kívüli kapcsolatok }\end{array}$ & 32,5 & 28,7 & 18,8 \\
\hline
\end{tabular}


5. táblázat: (folyt.)

\begin{tabular}{lccc}
\hline & \multicolumn{3}{c}{ Tanulmányi aktivitás változása } \\
\cline { 2 - 4 } $\begin{array}{l}\text { Intragenerációs intézményen } \\
\text { kívüli kapcsolatok változása }\end{array}$ & $\begin{array}{c}\text { Csökkent a } \\
\text { tanulmányi } \\
\text { aktivitás }(N=425)\end{array}$ & $\begin{array}{c}\text { Nem változott } \\
\text { a tanulmányi } \\
\text { aktivitás }(N=87)\end{array}$ & $\begin{array}{c}\text { Növekedett } \\
\text { a tanulmányi } \\
\text { aktivitás }(N=165)\end{array}$ \\
\hline $\begin{array}{l}\text { Nem változtak az } \\
\text { intragenerációs intézményen } \\
\text { kívüli kapcsolatok }\end{array}$ & 36,5 & $\mathbf{5 4 , 0}$ & $\mathbf{4 9 , 1}$ \\
\hline $\begin{array}{l}\text { Növekedtek az } \\
\text { intragenerációs intézményen } \\
\text { kívüli kapcsolatok }\end{array}$ & 31,1 & 17,2 & 32,1 \\
\hline \begin{tabular}{l} 
Összesen \\
\hline
\end{tabular} & 100,0 & 100,0 & 100,0 \\
\hline
\end{tabular}

Megjegyzés: Khi-négyzet próba, $p<0,001$, félkövérrel jelölve: adj. res. $>2$.

Forrás: Learning Alone adatbázis

Munkánk során a bizalomváltozás hallgatói kapcsolatok változásával való összefüggését is vizsgáltuk, s megállapítottuk, hogy a bizalom gyengülése az intergenerációs intézményen belüli $(p<0,001)$, illetve az intragenerációs intézményen kívüli $(p<0,05)$ kapcsolatokkal mutat szignifikáns összefüggést.

Az intergenerációs intézményen belüli kapcsolatok romlása kritikus szint alá csökkent. Mivel adataink szerint eleve alacsony szintű oktató-hallgató kapcsolat jellemezte a válaszadókat már a távolléti oktatás előtt is, ennek romlása fokozódó bizalmatlansággal járt együtt. A felsőoktatási intézményi szereplők közül általában még az oktatókban bíznak leginkább a hallgatók a rektorokkal, dékánokkal, adminisztrátorokkal és hallgatói képviselőkkel szemben (Pusztai 2011). Most ez is elillant, s ezt azért tartjuk különösen veszélyesnek, mert a bizalmatlanság az intézményből való kiábrándulás egyik jellemzője, ami szoros kapcsolatban áll a lemorzsolódási rizikó növekedésével (Fényes 2019; PusztaiKovács-Hegedüs 2019) (6. táblázat).

6. táblázat: $\mathrm{Az}$ intergenerációs intézményen belüli kapcsolatok és a bizalom összefüggése (\%)

\begin{tabular}{lccc}
\hline \multirow{2}{*}{$\begin{array}{l}\text { Intergenerációs intézményen } \\
\text { belüli kapcsolatok változása }\end{array}$} & $\begin{array}{c}\text { Csökkent a bizalom } \\
(N=370)\end{array}$ & $\begin{array}{c}\text { Nem változott a } \\
\text { bizalom }(N=160)\end{array}$ & $\begin{array}{c}\text { Növekedett a } \\
\text { bizalom }(N=177)\end{array}$ \\
\hline $\begin{array}{l}\text { Csökkentek az } \\
\text { intergenerációs intézményen } \\
\text { belüli kapcsolatok }\end{array}$ & $\mathbf{4 8 , 8}$ & 45,0 & 45,0 \\
\hline $\begin{array}{l}\text { Nem változtak az } \\
\text { intergenerációs intézményen } \\
\text { belüli kapcsolatok }\end{array}$ & 40,3 & 46,9 & 40,1 \\
\hline
\end{tabular}


6. táblázat: $\left(f_{\circ} l y t\right.$. $)$

\begin{tabular}{lccc}
\hline $\begin{array}{l}\text { Intergenerációs intézményen } \\
\text { belüli kapcsolatok változása }\end{array}$ & $\begin{array}{c}\text { Csökkent a bizalom } \\
(N=370)\end{array}$ & $\begin{array}{c}\text { Nem változott a } \\
\text { bizalom }(N=160)\end{array}$ & $\begin{array}{c}\text { Növekedett a } \\
\text { bizalom }(N=177)\end{array}$ \\
\hline $\begin{array}{l}\text { Növekedtek az } \\
\text { intergenerációs intézményen } \\
\text { belüli kapcsolatok }\end{array}$ & 10,9 & 8,1 & $\mathbf{2 4 , 3}$ \\
\hline Összesen & 100,0 & 100,0 & 100,0 \\
\hline
\end{tabular}

Megjegyzés: Khi-négyzet próba, $p<0,01$, félkövérrel jelölve: adj. res. $>2$.

Forrás: Learning Alone adatbázis

A távolléti oktatás alatt a válaszadók több mint a felénél csökkent a bizalom a megelőző időszakhoz képest. Ezen hallgatók közel felénél romlottak az intragenerációs intézményen kívüli kapcsolatok is. A járványhelyzet okozta elszigeteltség, a társas támasz hiánya összefüggésbe hozható a bizalmatlanság érzésének növekedésével (7. táblázat).

7. táblázat: Az intragenerációs intézményen kívüli kapcsolatok és a bizalom összefüggése (\%)

\begin{tabular}{lccc}
\hline $\begin{array}{l}\text { Intragenerációs intézményen } \\
\text { belüli kapcsolatok változása }\end{array}$ & $\begin{array}{c}\text { Csökkent a bizalom } \\
(N=370)\end{array}$ & $\begin{array}{c}\text { Nem változott a } \\
\text { bizalom }(N=160)\end{array}$ & $\begin{array}{c}\text { Növekedett a } \\
\text { bizalom }(N=177)\end{array}$ \\
\hline $\begin{array}{l}\text { Csökkentek az } \\
\text { intragenerációs intézményen } \\
\text { kívüli kapcsolatok }\end{array}$ & $\mathbf{5 1 , 8}$ & 41,9 & 40,1 \\
\hline $\begin{array}{l}\text { Nem változtak az } \\
\text { intragenerációs intézményen } \\
\text { kívüli kapcsolatok }\end{array}$ & 38,2 & 47,5 & 41,8 \\
\hline $\begin{array}{l}\text { Növekedtek az } \\
\text { intragenerációs intézményen } \\
\text { kívüli kapcsolatok }\end{array}$ & 10,0 & 10,6 & $\mathbf{1 8 , 1}$ \\
\hline Összesen & & & 100,0 \\
\hline
\end{tabular}

Megjegyzés: Khi-négyzet próba, $p<0,05$, félkövérrel jelölve: adj. res. $>2$.

Forrás: Learning Alone adatbázis

Az elégedettségnek a hallgatói kapcsolatok változásával való összefüggését vizsgálva szignifikáns együttjárás fedezhető fel az intragenerációs intézményen belüli $(p<0,01)$, az intergenerációs intézményen belüli $(p<0,01)$, valamint az intragenerációs intézményen kívüli $(p<0,001)$ kapcsolatok változása esetében is.

$\mathrm{A} z$ elégedetlenebbé váló hallgatók döntő többségének $(66,1 \%)$ csökkentek az intragenerációs intézményen belüli kapcsolatai, s elégedettebbek voltak azok, akiknek kevésbé lazultak meg a hallgatótársak felé mutató kontaktusai (8. táblázat). 
8. táblázat: Az intragenerációs intézményen belüli kapcsolatok és az elégedettség összefüggése (\%)

\begin{tabular}{lcc}
\hline \multirow{2}{*}{$\begin{array}{l}\text { Intragenerációs intézményen belüli kapcsolatok } \\
\text { változása }\end{array}$} & $\begin{array}{c}\text { Elégedettség változása } \\
(N=313)\end{array}$ & $\begin{array}{c}\text { Elégedettebb } \\
(N=364)\end{array}$ \\
\cline { 2 - 3 } $\begin{array}{l}\text { Csökkentek az intragenerációs intézményen belüli } \\
\text { kapcsolatok }\end{array}$ & $\mathbf{6 6 , 1}$ & 51,9 \\
\hline $\begin{array}{l}\text { Nem változtak az intragenerációs intézményen } \\
\text { belüli kapcsolatok }\end{array}$ & 28,8 & $\mathbf{4 0 , 4}$ \\
\hline $\begin{array}{l}\text { Növekedtek az intragenerációs intézményen belüli } \\
\text { kapcsolatok }\end{array}$ & 5,1 & 7,7 \\
\hline Összesen & 100,0 & 100,0 \\
\hline
\end{tabular}

Megjegyzés: Khi-négyzet próba, $p<0,01$, félkövérrel jelölve: adj. res. $>2$.

Forrás: Learning Alone adatbázis

Az elégedettebbé válók körében jelentősen magasabb az oktatókkal változatlan vagy intenzívebb kapcsolatot tartók aránya, mint azt az előző táblázatban a hallgatótársaknál láttuk. Az elégedetlenebbé váló hallgatók felénél pedig az oktatói kapcsolatok csökkenése jelentkezett. Ez megerősíti a kutatások azon álláspontját, miszerint az oktatókkal való szegényes vagy csökkenő kapcsolatok nagyban hozzájárulnak a hallgatók elégedetlenségéhez (Pusztai 2011). Úgy véljük, ez az eredmény, a bizalomhoz hasonló módon, az intézményből való kiábrándultság felé vezető út előjele (9. táblázat).

9. táblázat: $\mathrm{Az}$ intergenerációs intézményen belüli kapcsolatok és az elégedettség összefüggése (\%)

\begin{tabular}{lcc}
\hline \multirow{2}{*}{$\begin{array}{l}\text { Intragenerációs intézményen belüli kapcsolatok } \\
\text { változása }\end{array}$} & \multicolumn{2}{c}{ Elégedettség változása } \\
\cline { 2 - 3 } & $\begin{array}{c}\text { Elégedetlenebb } \\
(N=313)\end{array}$ & $\begin{array}{c}\text { Elégedettebb } \\
(N=364)\end{array}$ \\
\hline $\begin{array}{l}\text { Csökkentek az intergenerációs intézményen belüli } \\
\text { kapcsolatok }\end{array}$ & $\mathbf{5 1 , 8}$ & $\mathbf{3 8 , 2}$ \\
\hline $\begin{array}{l}\text { Nem változtak az intergenerációs intézményen } \\
\text { belüli kapcsolatok }\end{array}$ & 37,1 & $\mathbf{4 5 , 9}$ \\
\hline $\begin{array}{l}\text { Növekedtek az intergenerációs intézményen belüli } \\
\text { kapcsolatok }\end{array}$ & $\mathbf{4 5 , 9}$ & $\mathbf{4 5 , 9}$ \\
\hline Összesen & 100,0 & 100,0 \\
\hline
\end{tabular}

Megjegyzés: Khi-négyzet próba, $p<0,01$, félkövérrel jelölve: adj. res. $>2$.

Forrás: Learning Alone adatbázis

Az elégedetlenebbek 55\%-át képezték azok, akiknek az intragenerációs intézményen kívüli kapcsolatai is csökkentek. A COVID-19-helyzet alatt bevezetett korlátozások miatt lazuló kapcsolatok az intézménnyel való elégedettség növekedésével is együttjártak (10. táblázat). 
10. táblázat: Az intragenerációs intézményen kívüli kapcsolatok és az elégedettség összefüggése (\%)

\begin{tabular}{lcc}
\hline \multirow{2}{*}{$\begin{array}{l}\text { Intragenerációs intézményen kívüli kapcsolatok } \\
\text { vátozása }\end{array}$} & \multicolumn{2}{c}{ Elégedettség változása } \\
\cline { 2 - 3 }$(N=313)$ & $\begin{array}{c}\text { Elégedetlenebb } \\
(N=364)\end{array}$ \\
\hline $\begin{array}{l}\text { Csökkentek az intragenerációs intézményen kívüli } \\
\text { kapcsolatok }\end{array}$ & 55,0 & 39,0 \\
\hline $\begin{array}{l}\text { Nem változtak az intragenerációs intézményen } \\
\text { kívüli kapcsolatok }\end{array}$ & 35,1 & $\mathbf{4 6 , 7}$ \\
\hline $\begin{array}{l}\text { Növekedtek az intragenerációs intézményen kívüli } \\
\text { kapcsolatok }\end{array}$ & 9,9 & 14,3 \\
\hline \begin{tabular}{l} 
Összesen \\
\hline
\end{tabular} & 100,0 & 100,0 \\
\hline
\end{tabular}

Megjegyzés: Khi-négyzet próba, $p<0,001$, félkövérrel jelölve: adj. res. $>2$.

Forrás: Learning Alone adatbázis

Az eredmények alapján tehát elmondható, hogy a hallgatók kapcsolati redukciója jelentős összefüggést mutat a négy eredményességi változónkkal. Az intragenerációs intézményen belüli kapcsolatok erőssége jelentősen összefügg a tanulmányok melletti kitartás, a tanulmányi aktivitás és az elégedettség változásával. Az oktatóktól való eltávolodás a bizalom és az elégedettség gyors és erőteljes leépülését vonta maga után. A szülőkkel való kapcsolattartás erős kapcsolatban áll a hallgatók tanulmányi kitartásával és aktivitásával, az intézményen kívüli kortárs kapcsolatok pedig a tanulmányi aktivitáson kívül minden dimenzióval összefüggésben állnak.

$\mathrm{A} z$ elemzés utolsó lépésében megvizsgáltuk, hogy a négy eredményességi dimenzióban (tanulmányi kitartás, aktivitás, bizalom, elégedettség) tapasztalt, összesített s az átlagosnál erőteljesebb romlás esélyét melyik kapcsolati erőforrás gyengülése növelte leginkább a többi változó kontrollja alatt. A logisztikus regressziós elemzés ${ }^{3}$ szerint a legerősebben a hallgatótársak hiánya $(\exp (B)=1,828, p<0,01)$, azután a szülői kapcsolatok lazulása $(\exp (B)=1,623, p<0,05)$, majd az oktatói kontaktusok csökkenése $(\exp (B)=$ $1,473, p<0,05)$ növeli a hallgatói eredményesség romlásának esélyét. A többi változó kontrollja mellett az intézményen kívüli kortárs kapcsolatok nem számítanak befolyásos tényezőnek.

Ennek alapján elmondható, hogy a hallgatótársakkal, a szülőkkel és az oktatókkal fenntartott kapcsolatok befolyása egymástól független és erős. Ez az eredmény továbberősíti azt a tézist, miszerint az intézménybe jól beágyazott hallgató valójában a hallgatói társadalomba jól integrált hallgató. A szülők még a felsőoktatás alatt is igen fontos partnerei az oktatásnak a hallgatók tanulmányi kitartásának és aktivitásának fenntartása érdekében. Továbbá az oktatói kapcsolattartás, melyet tovább csökkentett a távolléti oktatás kontextusa, a képzés hatékonyságának szilárd támasza lehetne.

3 A modell függő változója 1-es értéket kapott, ha az átlagosnál erőteljesebb volt a romlás, vagyis amikor legalább két eredményességi dimenzióban romlás volt tapasztalható. 


\section{Összegzés}

Tanulmányunkban a „Learning Alone” kutatás COVID-19-pandémia első hulláma alatt felvett adatait elemeztük $(N=677)$. Az adatfelvétel során az elérhető legnagyobb hallgatói online közösséggel vettük fel a kapcsolatot, így az elemzés során levont következtetések a magyar hallgatótársadalomra nézve nem általánosíthatók.

Kutatásunk eredménye szerint a hallgatók tanulmányi aktivitása, tanulmányok folytatása melletti kitartása, bizalma és elégedettsége a tavaszi távolléti oktatás alatt egyöntetűen romlott minden szülői iskolázottsági csoportban. Az intergenerációs intézményen kívüli (szülői) kapcsolatokon kívül, minden más kapcsolati dimenzióban szignifikánsan csökkent a hallgatók kapcsolattartása.

Tanulmányunk célja az volt, hogy megvizsgáljuk, hogy ez a változás hogyan függ öszsze a hallgatók kapcsolati kontaktusainak változásával. A hallgatótársakhoz füződő kapcsolatok gyengülése hozható a leginkább összefüggésbe az eredményességgel: az intézményen belüli baráti kapcsolatok redukciójával párhuzamosan csökkent a tanulmányok melletti kitartás, a tanulmányi aktivitás, illetve az elégedettség. Az oktató-hallgató kapcsolattartás gyengülése együtt járt a bizalom és az elégedettség csökkenésével. A szülői kapcsolatok terén nem volt megállapítható szignifikáns csökkenés, mégis, akiknek lazult a kapcsolata a szüleivel, annak a tanulmányok melletti kitartása és aktivitása is csökkent. $\mathrm{A} z$ intézményen kívüli kortársakhoz füződő kapcsolatok csökkenése is összefüggést mutatott a tanulmányok melletti kitartás, az elégedettség és a bizalom csökkenésével, de a másik három kapcsolati dimenzióval szemben ennek nem volt jelentős, önálló befolyása a hallgatók eredményességének csökkenésére. Mindezek alapján hipotézisünk azon része megerősíthető, miszerint a hallgatótársak és az oktatók felé irányuló kapcsolatok redukciója növeli az eredménytelenség rizikóját.

Noha a járványhelyzet okozta távolléti oktatásra egy, az átlagosnál jóval szigorúbb távoktatási „kísérletként” is tekinthetünk - melyet természetesen súlyosbított az extraorganizációs kapcsolatok visszaesése is -, jelen kutatás felhívta a figyelmet arra, hogy a felsőoktatásnak a tudástranszfer mellett számos további funkciója is van. Mindennek tudatában fontos, hogy ismerjük az intézményen belüli kapcsolatok hiányából fakadó lehetséges következményeket annak érdekében, hogy az oktatás növekvő digitalizálódása mellett a felsőoktatásban folyó munka olyan formái alakuljanak ki a jövőben, amelyek képesek a hallgatót az intézmény társas közegébe integrálni.

\section{IRODALOM}

Arkhipova, V. A., Vasilyeva, L. G., Gurdzhiyan, V. L., Makarov, A. L., Mashinin, N. A., Nikitina, A. A. \& Magaramov, S. A. (2020) Features of Student Virtual Social Capital: Characteristics, Opportunities and Limits. EurAsian Journal of BioSciences, Vol. 14. No. 2. pp. 3725-3729.

Astin, A. W. (1993) What Matters in College: Four Critical Years Revisited. San Francisco, Jossey-Bass.

FÉNyes H. (2019) A lemorzsolódás okai és klaszterei. In: Kovács K. et al. (eds) Lemorzsolódott hallgatók 2018. Debrecen, CHERD. pp. 5-7. 
Ferdig, R. E., Baumgartner, E., Hartshorne, R., Kaplan-Rakowski, R. \& Chrystalla Mouza, C. (2020) Teaching, Technology, and Teacher Education during the COVID-19 Pandemic: Stories from the Field. AACE-Association for the Advancement of Computing in Education.

Hodges, C., Moore, S., Lockee, B., Trust, T. \& Bond, A. (2020) The Differences between Emergency Remote Teaching and Online Learning. Elérhető: https:// er.educause.edu/articles/2020/3/the-difference-between-emergency-remote-teachingand-online-learning. [Letöltve: 2021.02.07.]

KRISTóf Zs. (2020) International Trends of Remote Teaching Ordered in Light of the Coronavirus (COVID-19) and Its Most Popular Video Conferencing Applications that Implement Communication. Central European Journal of Educational Research, Vol. 2. No. 2. pp. 84-92.

Niemi, H. M. \& Kousa, P. (2020) A Case Study of Students' and Teachers' Perceptions in a Finnish High School during the COVID Pandemic. International Journal of Technology in Education and Science. International Journal of Technology in Eductaion and Science, Vol. 4. No. 4. pp. 352-369.

Pusztai G. (2011) A láthatatlan kéztől a baráti kezekig. Budapest, Új Mandátum Könyvkiadó.

Pusztai G., Kovács K. \& Hegedüs R. (2019) Lemorzsolódók tegnap, ma, holnap. Educatio, Vol. 28. No. 4. pp. 737-754.

Putnam, R. D. (2000) Bowling Alone: The Collapse and Revival of American Community. New York, Simon \& Schuster.

Rapanta, C., Botturi, L., Goodyear, P., Guàrdia, L. \& Koole, M. (2020) Online University Teaching during and after the Covid-19 Crisis: Refocusing Teacher Presence and Learning Activity. Postdigital Science and Education, Vol. 2. No. 3. pp. 923-945.

Tinto, V. (1975) Dropout from Higher Education: A Theoretical Synthesis of Recent Research. Review of Educational Research, Vol. 45. No. 1. pp. 89-125.

Williamson, B., Eynon, R. \& Potter, J. (2020) Pandemic Politics, Pedagogies and Practices: Digital Technologies and Distance Education During The Coronavirus Emergency. Learning, Media E Technology, Vol. 45. No. 2. 107-114.

A cikk a Creative Commons Attribution 4.0 International License (https://creativecommons.org/licenses/ by/4.0/) feltételei szerint publikált Open Access közlemény, melynek szellemében a cikk bármilyen médiumban szabadon felhasználható, megosztható és újraközölhető, feltéve, hogy az eredeti szerző és a közlés helye, illetve a CC License linkje és az esetlegesen végrehajtott módositások feltüntetésre kerülnek. (SID_1) 